\title{
Goar Abalan in Toba Batak Ethnic: Anthropolinguistic Study
}

\author{
Ida Basaria ${ }^{1}$, Parlindungan ${ }^{2}$, Yulianus Harefa ${ }^{3}$ \\ ${ }^{123}$ Lecturer of Cultural Studies, University of Sumatera Utara \\ Email:idal@usu.ac.id
}

\begin{abstract}
This study wants to show how important the role of language in understanding culture is; but conversely, the role of culture is also very important in understanding language. It is true communication in language will achieve the target if the communication participant places the language in its cultural context. The theoretical umbrella in this study is anthropolinguistics which is the place of language in the social and cultural context of its society; especially in the task of analyzing the naming process for the Toba Batak community. In general, the Toba Batak people have a unique procedure for naming a child. William Shakespeare once stated "What's in a name" that which we call a rose by any other name would smell as sweet. If you gave another name to the rose, it would still smell good.) On the other hand, for most cultures in Indonesia, especially the Batak Toba culture, a name is supposed to be a prayer, hope or desire of the person who gave the name. A name is given to someone to distinguish someone from others; to make it easier for family/community members to call him, order him if necessary. Names are created and used, to be called, for the sake of practicality in everyday life. In fact, the naming process and the meaning of people's names in the Toba Batak community cannot be separated from the cultural values adopted by the community. It is known that every naming process is always accompanied by the use of certain traditional rituals. In the Toba Batak community, there are three names (goar) based on the meaning of naming the child, namely goar tulut, goar abalan and mampe goar. However, this study wants to examine one of the three goars, namely the abalan goar given to their children. By using a qualitative descriptive method and an ethnographic approach, it will be studied and traced the existence of a connection between the meanings and cultural values of the abalan goar of the Toba Batak community.
\end{abstract}

Keywords: goar abalan, goar tulut, anthropolinguistics

\section{INTRODUCTION}

Language is a media used to express human thoughts and feelings. Language can not be separated from humans because language always follows every activity. Language is not only a thought but also a cultural development, language must be understood as part of culture. Like language, culture is learned, transmitted, and passed down from generation to generation through action and communication. The relationship between language and culture is very close. They complement and influence each other. Language comes from the mindset of humans who were born because of a set of human knowledge / understanding of their environment.(see Salzmann, Z. 2007; Markhamah. 2000 ; Rummens, 1993 )

The relationship between language and culture is indeed complementary and influential. Language comes from the mindset of humans who were born because of a set of human knowledge / understanding of their environment. The abstract language system has a very varied form, both variations in the form of any nuance of meaning in the context of speech.

One of the famous proverbs related to language is "language shows the nation" or "from the language of the nation's known" (Chaniago and Pratama, $2004: 81)$. This proverb can imply various things: from language can be known from which circle or social class that person comes from, it may also be known what region or ethnicity that person is from. Such is the close relationship between language and culture of the community that the name given by parents to their children in certain ethnic groups can also describe the 'cultural meanings and values' of that ethnic group.

The concept of naming is a sociocultural paradigm that exists in a society. As a form of realization of the concept of a sign system in language, its presence cannot be separated from the socio-cultural aspects that underlie it. Piliang (2012:348) states that in the context of cultural studies, the existence of signs and texts cannot be separated from the social context in which the signs 
and texts are located. Signs and texts can only function when they are used by the community or society. The use of this sign system is a form of convention that produces certain meanings and social values in society.

The description above indicates that the concept of naming a place is a form of linkage between language, culture, and thought. The relationship between these three things is a fundamental concept of the theory of linguistic relativity whose formulation is based on the Sapir-Worf hypothesis. The Sapir-Worf hypothesis (in Kramsch, 2001:11) states that the use of language affects the way a person thinks and behaves. Thus the naming process is the influence of the language, culture, and thoughts of the people concerned.

One of the proverbs related to the famous language is "Language shows the nation" or "From the language known to the nation" (Chaniago and Pratama, 2004: 81). This proverb can imply various things: from language it can be known from which social group or class the person comes from, it may also be known from which region or region or what ethnicity the person comes from. So closely related is the language and culture of the community so that the names given by parents to their children in certain ethnicities can also describe the 'cultural meanings and values' of that ethnicity.

Giving a name is essentially part of language activity. From the procedure for this naming, it is reflected how these ethnic attitudes and culture towards naming their children. Because language is the most important element of a culture (Koentjaraningrat, 1981 : 57), then the use of language for the sake of naming also reflects the attitude and cultural views of its users towards the language concerned.

On the other hand, for most cultures in Indonesia, including the culture of the Toba Batak people, a name is a prayer, hope or desire of the person who gave the name. A name is given to someone to distinguish them from others; to make it easier for family/community members to call him, order him if necessary. Names are created and used, to be called, for the sake of practicality in everyday life. In fact, the naming and meaning of people's names in the Toba Batak community cannot be separated from the cultural values adopted by the community. Because the naming process is always accompanied by the use of certain traditional rituals. In the Toba Batak community, there are three names (goar) based on the meaning of naming the child, namely goar tulut, goar abalan and mampe goar. This study wants to examine one of the three goars, namely the abalan goar given to their children. By using a qualitative descriptive method with an anthropolinguistic approach, it will be studied and explored how the cultural meanings and values of the Toba Batak people's goar are

\section{RESEARCH METHODS}

The population of this research is the Batak Toba community members who live in the research location, city of Tarutung, aged $<10$ years to 60 years. The main research data were obtained from respondents' answers obtained through survey questionnaires, in addition to data from ethnographic methods with involved observation and interview techniques. Data collection is done by observation, questionnaires, and interviews. (see approach (Spradley, 1997; Sugiyono, 2017; Idrus, 2007; Moleong, 2007) Data in the form of 30 ethnic Batak Batak Toba names are assumed to have a certain meaning Purposely collected by observing a number of lists. Names that describe cultural values are also analyzed. Because it is qualitative, data collection in the form of names of the community is not limited based on the number (population or sample), rather it is collected based on the needs of achieving the research objectives themselves (purposive sampling). Data which is considered valid in achieving research objectives, is described before being analyzed qualitatively, namely by understanding in depth the results of the questionnaire and the overall interview as well as reviewing it based on the concepts that have been chosen as the basis of research. The results of the analysis are presented informally, namely in the form of a description in the form of words and obtained is the result of an agreement between the researcher and the informants. Based on the results of the analysis drawn an inductive conclusion in the form of the meaning of the ethnic names.

\section{DISCUSSIONS}

In giving the name of the child, each parent has their own goals and expectations as the implementation of his mind. A child's name as well as language can provide a description of the way of thinking of his parents. Some parents choose extraordinary names for their children. While for certain circles there is a belief that if a child "objected to the name" can later be sick. There are some parents who consider the name as something ordinary, just an identity that distinguishes one person from another. There are others who choose names for their children based on a sense of appreciation for someone who is deemed meritorious or admired.

\subsection{The Meaning of The Name of The Toba Batak People}

Panggoaran name is the name given by parents since the child/baby they are born is still small. Usually the naming is accompanied by hopes and prayers of kindness carried out through the manggoar dakdanak tubu traditional ceremony (the custom of naming a newborn child). From observations in the field, based on its meaning, the name of the Toba Batak people can be grouped into several meanings which will be described in the section below

\subsubsection{Goar Abalan}

In the Toba Batak community, the meaning of abalan is an empty space that can be developed in various 
interests. Found the word abalan ni huta, or abalan ni uma, is means an empty space around the gate entrance (harbangan ) of the hillage. It is used as convention (partungkoan ) or a temporary resting place for guests who will carry out customs to the residents of the village.

Goar abalan is given with the hope that the child whose name is given will get luck in accordance with the name. In social life, especially in the Toba Batak tribe, the meaning of the name abalan is often found. If the goar abalan cannot be carried, usually the name is replaced with another name by the manggoar-goar process. With a special traditional process by preparing itak gurgur 'Batak cake consisting of rice flour whose size is shaped/printed with the maker's fist'

At the event, parents and children will go around the village to meet all the residents / clans, tell them the new name and they are given the itak gurgur cake.

Itak gurgur is a kind of cake made from rice flour mixed with brown sugar, a little black pepper and salt and grated young coconut. These ingredients are mixed with a little water and shaped / molded with adult dough and served without cooking first. It feels very distinctive because this autumn itak only exists at special traditional parties for naming events and at certain traditional events such as the traditional event of entering the new house of the Toba Batak people.

\subsubsection{Tulut Goar.}

In the Toba Batak community, names are also found which are a reminder of the life experiences of those closest to them, such as memories of parents and children's closest relatives. Goar tulut is intended because there are memories of those who have names, memorable in their lives (for example, there are memories of helping her delivery process). For example, the name Paet'si bitter' becomes the name tulut (tulutan) because so far the parents of children have been living hard and always in suffering.

Mampe Goar

In this society, giving ancestral names can be given to children who are born. This is done if the name of the leleuhur becomes a great name and is positively famous during his lifetime in the wider community. Because the ancestral name cannot be arbitrarily carried by his descendants, all clans descended from that ancestor must be invited to menbalkan the name of the mampe goar. The purpose of giving mampe goar is to honor the ancestor name as reminder of life time in the past to be known at present or even in the future

The name given by parents to their children is an expression of the values of their ethnic culture. Usually the naming is accompanied by hopes and prayers of kindness those are carried out through the ceremonies called manggoar dakdanak tubu (customary naming of newborn children).

The table below contains 30 names of Batak Toba ethnic children, tabulated entirely based on three meanings, namely the meaning of hope / futurative, situational meaning and the meaning of memories. Goar Abalan contains the meaning of hope. Goar Tulut is a meaning that states the existence of certain events or memories when the child is born. There are two meanings found in tulut goars, namely situational meaning and memorable meaning. . How about mampe goar? It is called mampe goar if the name given to the child is the name of an ancestor who is considered sacred or considered famous during his lifetime. At this time mampe goar is rarely found, especially in the Toba Batak community in the city. Even if it's still found, it's a long way to find the mampe goar

\begin{tabular}{|l|l|l|l|l|l|}
\hline NO & Name & \multicolumn{1}{|c|}{ Meaning of Name } & $\begin{array}{l}\text { Futurative } \\
\text { Meaning }\end{array}$ & $\begin{array}{l}\text { Situational } \\
\text { Meaning }\end{array}$ & $\begin{array}{l}\text { Meaning of } \\
\text { Memories }\end{array}$ \\
\hline 1 & Bungaran & blooming & $\mathrm{V}$ & & \\
\hline 2 & Bonar & truly & $\mathrm{V}$ & & \\
\hline 3 & Haposan & Sure, believe & $\mathrm{V}$ & & \\
\hline 4 & Panangian & Hearing, obeying & $\mathrm{V}$ & & \\
\hline 5 & Monang & Win & $\mathrm{V}$ & & \\
\hline 6 & Binsar & Clever boy, rise & $\mathrm{V}$ & & \\
\hline 7 & Anju & patient & $\mathrm{V}$ & & \\
\hline 8 & Gabe & Good and succeed & $\mathrm{V}$ & & \\
\hline 9 & Domu & friendly & $\mathrm{V}$ & & \\
\hline 10 & Dame & peace & $\mathrm{V}$ & & \\
\hline
\end{tabular}




\begin{tabular}{|c|c|c|c|c|c|}
\hline 11 & Lintong & Clear as water & $\mathrm{V}$ & & \\
\hline 12 & Patar & - transparent & $\mathrm{V}$ & & \\
\hline 13 & Sihol & missed & $\mathrm{V}$ & & \\
\hline 14 & Bontor & sincere & $\mathrm{V}$ & & \\
\hline 15 & Gomgom & leader & $\mathrm{V}$ & & \\
\hline 16 & martua & Long live & V & & \\
\hline 17 & Jogi & - captivate & $\mathrm{V}$ & & \\
\hline 18 & Togar & Strong & $\mathrm{V}$ & & \\
\hline 19 & Timbul & Appear / be seen & $\mathrm{V}$ & $\mathrm{V}$ & \\
\hline 20 & $\operatorname{Tog} u$ & Hold & $\mathrm{V}$ & & \\
\hline 21 & Mora & Rich & $\mathrm{V}$ & & \\
\hline 22 & Ronggur & Fast/strong & $\mathrm{V}$ & & \\
\hline 23 & Tumpak & help & V & & \\
\hline 24 & Hokkop & embrance & V & & \\
\hline 25 & Kombang & Flourished & V & & \\
\hline 27 & Lokot & Sticky / every attempt is successful & & $\mathrm{V}$ & $\mathrm{V}$ \\
\hline 28 & Luhut & all gathered & $\mathrm{V}$ & & \\
\hline 29 & Haposan & Trust & $\mathrm{V}$ & & \\
\hline 30 & Sangkot & Captured / stopped / stuck & & $\mathrm{V}$ & $\mathrm{V}$ \\
\hline
\end{tabular}

From the table above we can find thirty names of Batak Toba people. A close relationship was found between the child's name and his parents' expectations as part of the Batak Toba ethnic. Generally, each name shows the meaning of the name that glorifies, goodness, bravery, tenderness, charm, obedience and others that can be grouped into 3 groups of meanings. The first group futurative meaning/ meaning of hope, the second group situational meaning, and the third group meaning of memories. From the observations seen parents try to give the names of their children with the best names according to them. Names of children can be grouped into several meanings which will be described in the section below.

This futurative meaning is the meaning of the name that contains hope so the life will be like the meaning of its name. In social life, especially in the Batak Batak Toba ethnicity, the name with futurative meaning is often found. In general, a name implies hope which concerns the future of their child (the owner of the name). Everyone's expectations will always be good, even though they may not always be fulfilled according to the meanings contained in these names. At the very least, it is hoped that the children bearing the name will be reminded that they have names that carry good meanings. So, if they will do bad things, they will think and shame to do those things.

So in general the name given is the hope of his parents towards their children. In other words, almost all parents have good hopes for their children and these expectations are displayed through their names

Goar tulut contains a situational meaning that contains meaning of certain situations or circumstances that occur when a child is born. It means that the situational name is given according to the situation and condition at the time the child is born.

The name is given in accordance with the memories experienced by parents when the child is born. The name for situational meaning is always also intended to remember the events referred to when the child was born. It means that every name that contains situational meaning must also contain meaning of memories; likewise the name of memories also refers to the situation when the child was born. Giving names with the intention of situational meaning / memories is not so much found. There are 2 data names found from 
the table above which contain situational meanings and memories, namely ; Kombang 'flourished'and Lokot'sticky'.

Two names that contain situational meaning and at the same time contain meaning of memories are 1) Sangkot means stuck or stopped is the situation of the child when born. From observations in the field it is known that babies are very difficult when born, even as if it was stuck or stopped by their own umbilical cord wrapping in the mother's womb. This situation causes children born directly given the name Sangkot. As well (2) name of Lokot given based on the situation at birth. besides referring to the situational meaning as well as being given to the meaning of memories. Parents want to commemorate the situation of the child's birth by giving meaning to the situation of the child with the name of Sangkot and Lokot. So the words Sangkot and Lokot contain situational meaning and the meaning of memories. If the names of Sangkot and Lokot only contain situational meaning / memories,

\subsection{The Relationship The Name and Culture of The Toba Batak Community}

In the life of the Batak Toba people, cultural values are stored in traditional languages, traditional houses, traditional ceremonies, old myths, Batak batik and its make-up, tortor as a typical Toba Batak dance, music, and social or customary systems. which is in accordance with Natolu's argument (Sumardjo, 2003). From this opinion, it can be predicted that the naming of the Toba Batak people is a reflection of their ethnic culture. In the view of other ethnic groups, the Toba Batak people have a hard-working stereotype. The fact that the culture of hard work is the identity of the Batak people is undeniable. In the famous Bataknese song entitled "Anakhon I do hamoraon di au" one verse is 'hugogo pe mansari, arian nang botari..laho pasingkolahon gelengki 'I work as hard as I can, day and night so I can send my children to school'... ' depiction of this ethnic hardworking culture. It can be strongly suspected that many of Binsar's names were 'rise'; Monang 'win', Gabe 'successfully', Timbul 'rises' and Kombang ' Flourished ' which is found in the name of the Toba Batak people is a display of the cultural values of the people's hard work. Because the goal of achieving the hope of becoming a twinkling, win, successfully, arising and Flourishing like the meaning of these names can only be achieved through hard work

Furthermore, the existence of a mutual cooperation culture in the Toba Batak ethnicity cannot be denied anymore. This can be seen in the daily life of the Batak people at events of joy (traditional weddings) and mourning (customs of death). The number of relatives who attended the two events, up to hundreds and even thousands of people who attended, by providing 'help'; is an indication of the existence of a culture of mutual cooperation in this ethnic group. From the table above, it can be seen that the names Togu 'help', Tumpak 'assistance in the form of money' and Hokkop 'embrace' which are widely used are reflections of the culture of gotong royong. Because the meaning of these names is a form of solidarity and assistance to others.

From the explanation above, it can be stated that there is a connection between the vocabulary of the Batak people's names and cultural values that are multidirectional. Giving a child's name, of course, is not just given carelessly, because parents have a desire or reason for choosing the child's name. Through the name, parents hope that the child will become the person they want to be. Parents have a reference behind the choice of a child's name. References for naming are often associated with referents. The name of the Batak people is a product of their society which is able to explain the state of various things about their society. So that through the names given, they can actually display the 'habits' which are the culture of the Toba Batak people

\section{CONCLUSIONS}

1. Goar abalan are names that have the meaning of hope The meaning of this futurative name is the meaning of the name which contains the hope and the life of the owner of the name will be like. In the Batak Batak Toba community, names that contain futurative meanings are found. The hope is that their children will become good people, even though they may not always be fulfilled according to the meaning contained in the name given. At least it is expected that children bearing the name will be reminded that they have names that carry good meanings. So, if they will do bad things, they will think and shame to do it.

2. Goar tulut are names whose meanings contain hope The situational meaning found in a child's name almost always contains the meaning of memories as well. This means in every situational meaning always brings memories to the process of naming the child. So the situational meaning is very close to the meaning of memories. The name given often displays the cultural values of the Batak Toba people. It means that there is a close relationship between the name as a language container and the cultural values of the Batak Toba community. For example, the name Muhammad Rizki actually can describe the religious values adopted by the community.

\section{ACKNOWLEDGMENTS}

The research team would like to thank the USU Research Institute for giving the trust to carry out this research. This article is part of the USU TALENTA research entitled: Meaning of Goar Abalan Toba Batak Community: Antropolinguistic Study . Youth for Fiscal Year 2021. No.: 272/UN5.2.3.1/PPM/SPP-TALENTA USU/2021 


\section{REFERENCES}

[1] Chaniago, N.A. \& Pratama, B. 200. 7700 Peribahasa Indonesia. Bandung: Pustaka Setia.

[2] Idrus, M.2007.

[3] Ullmann, Stephen. 2017. Meaning and Style. Basil Blackwell : Oxford

[4] Kramsch, Claire. 2001. Language and Culture. Oxford: Oxford University Press.

[5] Lyons, J.1995. Introduction to Theoretical Linguistics. London: Cambridge University Press

[6] Markhamah. 2000 . Etnik Cina: Kajian linguistik kultural. Surakarta: Muhammadiyah Univiversity Press.

[7] Meleong,L.J.2007. Metode Penelitian Kualitatif Edisi Revisi Remaja Rosdakarya

[8] Rummens J.. 1993. "Personal Identity and Social Structure in Saint Maartin: A Plural Identity Approach". Unpublished Thesis/Dissertation, York University

[9] Salzmann, Z. 2007. Language, culture, and society (edisi keempat). Colorado: Westview

[10] Sibarani.Robert.2004.Antropolinguistik,Atropologi Linguistik, Linguistik Antropologi. Medan : USU Press

[11] Sugiyono. 2017. Metode Penelitian Kuantitatif, Kualitatif, dan R \&D Alfabeta

[12] Spradley, J.P. 1997. Metode Etnografi. Terjemahan oleh Misbah Yulfa Elisabeth.Yogyakarta : PT Tiara Wacana Yogya

[13] Piliang, Yasraf Amir. 2012. Semiotika dan Hipersemiotika. Bandung: Matahari.

[14] Harahap, Basyaral Hamidy. 2008. Orientasi NilaiNilai Budaya Batak.: Sanggar Willem Iskandar. Universitas Michigan

[15] Nalom Siahaan, Adat Dalihan Na Tolu: Prinsip dan Pelaksanaanya, Medan: Prima 